Centre for Evidence Based Medicine, Nuffield Department of Primary Care Health Sciences, University of Oxford, Oxford

jeffrey.aronson@phc.ox.ac.uk Cite this as: BMJ 2021;375:n2777 http://dx.doi.org/10.1136/bmj.n2777 Published: 12 November 2021

\section{When I use a word .... Nasty medical eponyms}

When Jewish physicians and scientists were dismissed from their posts by the Nazis in the 1930s, or left voluntarily, their places were often taken by Nazi sympathizers, all too willing to take part in the various Nazi programmes of human experimentation, forced sterilization in the name of eugenics, euthanasia, and genocide. Several medical eponyms memorialize such individuals. However, alternative descriptions of the diseases, syndromes, tests, and therapies that they described are available. Such descriptions can and should be used in place of the eponymous attributions. There is some evidence that this is happening increasingly.

Jeffrey K Aronson,

Two German physicists are currently in the news, Philipp Eduard Anton von Lenard (1862-1947) and Johannes Stark (1874-1957). Both won Nobel prizes and both were vociferous supporters of the Nazi party.

Lenard was the sole winner of the Nobel Prize in Physics in 1905, having been nominated 13 times, "for his work on cathode rays," a form of radiation that was emitted by hot metals. Stark won the prize in 1919, again the sole winner, having been nominated 11 times, including three times by Lenard, "for his discovery of the Doppler effect in canal rays and the splitting of spectral lines in electric fields." In the so-called Stark effect, an electric field can be seen to split the spectral lines emitted by atoms and molecules.

In the 1920s Stark and Lenard supported the Nazi party, and in 1924 they espoused the antisemitic Deutsche Physik movement, promulgating the view that "Aryan physics" was proper physics, in contrast to what they called Jewish physics, which, they claimed, was based on hypothetical calculations without an evidential basis, and therefore fallacious. They were particularly incensed by the fact that Albert Einstein was awarded the Nobel Prize in 1921 "for his services to Theoretical Physics, and especially for his discovery of the law of the photoelectric effect." 1 When, in May 1933, the Deutsche Studentenschaft led the burning of thousands of books by Jewish authors, those of Einstein were among them. Einstein later joined the board of the American Library of Nazi-Banned Books, which was established in the Brooklyn Jewish Center in New York in $1934 .^{2}$

The Philipp Lenard Schule, which is what the Helmholtz-Gymnasium Heidelberg was called between 1927 and 1945, was renamed after the war. And the International Astronomical Union, which had previously given Stark's and Lenard's names to craters on the moon in 1970 and 2008 respectively, dropped them in 2020. ${ }^{3}$ In parallel with those changes, there have recently been calls for the Stark effect to be renamed. It has also been proposed that Stark and Lenard should be stripped of their Nobel prizes. 4

These calls find echoes in similar calls that have been made in the past in respect of medical scientists who were also supporters of Nazi ideology.
When Jewish physicians and scientists were dismissed from their posts by the Nazis, or left voluntarily, their places were often taken by Nazi sympathizers, all too willing to take part in the various Nazi programmes of human experimentation, forced sterilization in the name of eugenics, euthanasia, and genocide..$^{-8}$ The list of the Jewish scientists who fled abroad and enriched science in other countries, to which they became "Hitler's gift," is a distinguished one. ${ }^{9}$ Among those who came to Britain in the 1930 and made major contributions in my own field were Hermann ("Hugh") Blaschko, Edith Bülbring, Hans Kosterlitz, Heinz Otto Schild, and Marthe Vogt.

Several medical eponyms memorialize Nazi medical scientists. Here is a list, undoubtedly incomplete, of some of the more egregious examples, with the names of the scientists and the entities for which they are eponymously remembered ${ }^{10-12}$ :

Eppinger, Hans: spider naevi

Hallervorden, Julius and Spatz, Hugo: neuroaxonal dystrophy

Dbrahim, Murad Iussuf Bey (with Soma Cornelius Beck, a Jewish dermatologist, d. 1930): congenital cutaneous candidiasis

[Reiter, Hans Conrad Julius: (a) reactive arthritis; (b) a complement fixation test for syphilis

Seitelberger, Franz: infantile neuroaxonal dystrophy

Stoeckel, Walter: pubovaginal fascial sling operation for stress incontinence

WWagner-Jauregg, Julius: use of malaria to treat syphilis

WWegener, Friedrich: necrotizing granulomatous vasculitis moon in 1976, but that was dropped in 2002 and later the former name, Euclides D, was reinstated.

The interaction of an electric field with an atom is a real effect. Had it been described by a Jew, the Nazis would have denounced it. Simply because it was discovered by a Nazi is no reason for us to do likewise. However, there is equally no reason for us to continue referring to it eponymously in the name of its discoverer.
Eppinger's name was also given to a crater on the 
Similarly, there is no reason to continue to dignify the various medical diseases, syndromes, and tests that are eponymously designated by the names of Nazi medical scientists.

There is a difficult tension between, on the one hand, the Whiggish view of history that judges past events in the light of current attitudes, and seeks, for example, to destroy statues of individuals, some of whose actions in the past would today be considered reprehensible, and, on the other hand, the recognition that those same individuals may have made positive contributions.

It is not easy to resolve this tension, and there are many arguments that justify, for example, either the destruction of statues or their preservation, either the cancelling of Nobel Prizes or their retention. However, where eponyms are concerned it is not hard to see a solution. Alternative descriptions are available; they can and should be used. ${ }^{13}$

Competing interests: none declared

1 Ball P. Serving the Reich: The Struggle for the Soul of Physics under Hitler. The University of Chicago Press, 2014doi: 10.7208/chicago/9780226204604.001.0001.

2 Ovenden R. Burning the Books. A History of Knowledge Under Attack. John Murray, 2020doi: 10.4159/9780674249509.

3 International Astronomical Union. Gazetteer of Planetary Nomenclature. https://planetarynames.wr.usgs.gov/Feature/5683 and https://planetarynames.wr.usgs.gov/Feature/14503?_fsk=401181506

4 Macintyre B. 'Führers of physics' shame the Nobel prize. The Times. 6 November 2021. https://www.thetimes.co.uk/article/fuehrers-of-physics-shame-the-nobel-prize-lp0tg26k9

5 Cohen E. The Nazification of German physicians, 1918-1937. Ann R Coll Physicians Surg Can 1998;31:336-40.pmid: 12382662

6 Shevell MI. Neurosciences in the Third Reich: from ivory tower to death camps. Can J Neurol Sci 1999;26:132-8. doi: 10.1017/S0317167100051842 pmid: 10352874

7 López-Muñoz F, Alamo C, García-García P, Molina JD, Rubio G. The role of psychopharmacology in the medical abuses of the Third Reich: from euthanasia programmes to human experimentation. Brain Res Bull 2008;77:388-403. doi: 10.1016/j.brainresbull.2008.09.002 pmid: 18848972

8 Martin M, Fangerau H, Karenberg A. Österreichische Neurologen unter dem Hakenkreuz: Julius Wagner-Jauregg - Walther Birkmayer - Franz Seitelberger. Nervenarzt2020;91(Suppl 1):100-8. doi: 10.1007/s00115-019-00848-1 pmid: 32067091

9 Pyke D, Medawar J. Hitler's Gift: Scientists Who Fled Nazi Germany. Richard Cohen Books, 2000

10 Strous RD, Edelman MC. Eponyms and the Nazi era: time to remember and time for change. ISr Med Assoc J 2007;9:207-14.pmid: 17402342

11 Kondziella D. Thirty neurological eponyms associated with the nazi era. Eur Neurol2009;62:56-64. doi: 10.1159/000215880 pmid: 19407456

12 Kondziella D, Zeidman LA. What's in a name? Neurological eponyms of the Nazi era. Front Neurol Neurosci 2016;38:184-200. doi: 10.1159/000442683 pmid: 27035717

13 Lu DW, Katz KA. Declining use of the eponym "Reiter's syndrome" in the medical literature, 1998-2003. J Am Acad Dermatol 2005;53:720-3. doi: 10.1016/j.jaad.2005.06.048 pmid: 16198806 